\title{
THE ELECTION RESULT AND ITS IMPLICATIONS FOR POLITICAL PARTY CONFIGURATION
}

\author{
By \\ Laurence Piper \\ Laurence Piper is Senior Lecturer in the School of Politics, \\ University of KwaZulu-Natal, Pietermaritzburg \\ Private Bag X01Scottsville 3209 \\ Tel: +27(0)33 260.5892; Fax: +27(0)33 260.5092 Cell: +27084 247.0609 \\ e-mail: piper@ukzn.ac.za
}

\begin{abstract}
As a competition for both popular support and political office, Election 2004 deepened the dominant-party system in South Africa. In terms of support, the African National Congress (ANC) did better than ever. Indeed, its leadership seemed more concerned about internal left-wing politics than about rival parties. Conversely, with the partial exception of the Democratic Alliance (DA), opposition parties did worse, and appear stuck in a zero-sum competition amongst themselves. In terms of office, ANC popularity meant greater national power and, for the first time, control of all provinces. Further, Election 2004 revealed that the more the ANC cooperates with its alliance partners the better it does at the polls, and the more influence the Congress Of South African Trade Unions (Cosatu)/South African Communist Party (SACP) have over policy. For opposition parties this dynamic is reversed. Those parties which co-operated with the ANC to get office lost popular support, while those which eschewed office did better at the polls. In sum, while popularity and office are mutually reinforcing for the alliance, they constitute a dilemma for opposition parties. Finally, while there are signs that broader social change will pose some class-related problems for the ANC, more profound racial obstacles await opposition parties. All this suggests that ANC dominance will grow still further in 2009.
\end{abstract}

\section{INTRODUCTION}

The outcome of Election 2004 and the trends in party support over the ten years of post-apartheid politics are important in determining government policy, the nature of the political system, and the consolidation of South Africa's young democracy. However, this paper will not address these questions directly. Rather it will address what the election means for the primary objective of parties in democracies: contesting political office through elections. As Joseph Schumpeter (1987, p 283) argues, 'a party is a group whose members propose to act in concert in the 
competitive struggle for political power'. While it is the case that parties have various functions like goal formation, interest articulation, popular politicisation and mobilisation, and elite recruitment, these all flow from their role in linking the institutions of state to civil society. Without access to office all these other functions become pretty meaningless or unsustainable, and without elections (democratic) access to office is nearly impossible.

This starting point means that party configuration in South Africa is orientated towards two, closely related, objectives: securing popular support and accessing political office. While elections directly link support to office, outright electoral victory is not the only way in which parties can gain office. Thus, under certain electoral outcomes, minority parties can form alliances amongst themselves to govern. Further, the advent of floor crossing in South Africa has extended the possibilities of parties manoeuvring to access power without elections. For example, the Independent Democrats were launched as a result of floor crossing and had seats in Parliament before winning votes in an election. Conversely, access to office has a significant impact on electoral success. Indeed, one of the main claims of this paper is that access has had divergent consequences for the electoral success of the ANC and opposition parties. Consequently, the paper will review South African political party configuration in light of Election 2004 in terms both of competition for popular support and access to political office, reflecting on party strategies and exploring future scenarios.

In terms of popular support, Election 2004 was not really about the ranking of parties in the final result, as this was widely anticipated, but more about the extent of party support. In this respect, the paper makes two claims. First, Election 2004 revealed a growing electoral dominance by the ANC. Indeed, analysis of the electioneering reveals that the ANC elite's main concern was not an existing opposition party but a spectre that haunts the liberation movement: a lingering left-wing politics within. In this sense then, the real victory of the ANC in Election 2004 was less over an external party than over an internal disillusionment constructed in a left register. Second, Election 2004 confirmed the dwindling popularity of opposition parties and the disengagement of many opposition supporters.

In terms of access to office, Election 2004 both extended the ANC's national dominance over the constitutionally significant two-thirds mark and secured it the governments of all nine provinces for the first time. Conversely, the election was bad for opposition parties, with the Inkatha Freedom Party (IFP) losing KwaZuluNatal, and the DA failing to access office in the Western Cape, Gauteng or KwaZuluNatal. Further, the election revealed a fascinating divergence in the relationship between party configurations and support at the polls. For the ANC, toenadering (getting together) with its alliance partners was good for electioneering and gave Cosatu and the SACP greater influence over government policy, at least for a time. For opposition parties however, access to office and popularity seem to exist in tension in the sense that those parties that chose to co-govern with the ANC did 
poorly at the polls, whereas those which distanced themselves from ANC office did better. In short, opposition parties currently find themselves on the horns of a dilemma in South African politics where they must choose between access to power and greater electoral support, but cannot have both.

To my mind the outcomes of party competition for popular support and access to office in Election 2004 confirm trends in the political system that have been evident since 1994. The inverse relationship between popular support for the ANC and that for the opposition is mirrored in an inverse dividend from party co-operation in accessing political office. It is my view that all this suggests a deeper bifurcation of the South African electorate into two major groups - one for the government and one against - groups whose allegiances have proved remarkably stable over time. Moreover, I argue that the identity of these groups is linked to enduring apartheid era relations of racial, class and ethnic power such that today's government supporters were the unambiguous 'losers' under the apartheid system, whereas today's opposition voters were the comparative 'winners' in the past. Notably, this boundary seems the most fundamental one in the popular political landscape, with parties struggling to attract votes across this divide. This said, there is some evidence that the boundary is becoming more porous, although mostly in one direction - towards the ANC. The paper finishes by exploring key changes in the institutions of state, market and public sphere which help explain this emerging mobility, arguing that they suggest better fortunes for the ANC than for opposition parties. In short, there are good reasons to assume that, as long as the ANC attends to class-related challenges its dominance will increase in Election 2009 and probably even beyond.

In developing this argument I begin by considering the $\mathrm{ANC}^{\prime}$ 's performance in 2004 in respect both of popular support and access to political office. I then examine opposition parties in the same way.

\section{The ANC in Election 2004 The Surprising Popularity of the ANC}

As Southall (2004, p 3) observed, everybody knew that the ANC was going to win Election 2004, but 'it was the manner of its winning that confounded observers'. Many anticipated that the ANC would have a reduced majority and the DA would make gains as the principal opposition party. Two main reasons were given for the ANC's anticipated decline: the waning of the 'liberation factor' and the failures of delivery. Additional reasons included Thabo Mbeki's alleged lack of popular magnetism, the Government's poor record of job creation, and policies on HIV/ AIDS and Zimbabwe. However, not only did the ANC do better than ever, the DA's gains were comparatively modest, the New National Party (NNP) was effectively destroyed and the IFP suffered moderate but significant damage, losing control of the province of KwaZulu-Natal. 
In explaining the ANC's success, indeed in characterising party competition during Election 2004 more generally, most analysts have emphasised three variables: party 'branding', resources and organisation. While there is much to this approach I want to suggest that a closer look at the content and style of the ANC's campaign reveals a further, and crucial, element in party competition for the ruling elite: an internal left-wing politics. Much of the ANC's campaign in 2004, indeed, much of the ANC's politics of late, is not directly externally at opposition parties but internally at a left-wing politics that haunts party leadership, principally through the alliance. Let's begin with the conventional analysis of Election 2004.

The ANC did better in Election 2004 than ever before, both in terms of its total national support and its reach across the country. As shown in Table 1 it achieved the highest percentage of the vote yet in a post-apartheid election, with 69,68 per cent. It also improved on the absolute number of votes it won in 1999 by some 276921 votes. Perhaps more importantly, Election 2004 revealed the ANC to be the largest party in all nine provinces for the first time. As shown in Table 2 (Sachs 2004, p 8) the ANC was especially impressive in the provinces of KwaZulu-Natal, the Western Cape and the Northern Cape, indeed, it was only in these three that the ANC did better in 2004 than in 1994. This is significant as the ANC lost to other parties in these provinces in 1994, securing the Northern Cape in 1999 and the Western Cape and KwaZulu-Natal in 2004. As in 1994 and 1999, the vast majority of ANC support came from black and poor people, and it was they who voted for the ANC (Reynolds 1994, p 190; 1999, p 181; Sachs 2004, p 12).

In the aftermath of the ANC's victory many reasons have been advanced for the party's impressive showing, including the weakness of opposition parties and some strategic mistakes. However, many of the reasons given reflect creditably on the ANC, including a carefully conceptualised and well organised campaign (Lodge 2005); the strength of the ANC as an organisation, especially the revitalisation of branch structures in the previous couple of years (Lodge 2004); the vigorous defence of its record in government in the previous ten years (Southall 2004) and the ANC's effective use of the ten-year anniversary of democracy.

This story of the ANC's success, or a version similar to it, is pretty much common cause amongst the various commentators on South African politics. However, I want to suggest that it is important to analyse the specific content, and especially the style, of the ANC's campaign as it reflects a notable ideological difference from those of the major opposition parties, namely a left-leaning concern with the poor, the unemployed and the working class. While all significant parties talked about the same five problems (unemployment, poverty, HIV / AIDS, crime and corruption), the ANC did not speak about them in the neo-liberal register of the DA and IFP or, for that matter, of the Growth, Employment and Redistribution Policy (Gear), but in the left register of its alliance partners. This concern with working-class politics is reflected both in the style of the ANC's 2004 campaign, and in the kind of political issues which have been foregrounded by Mbeki for his second term. In sum, Election 2004 saw the ANC return to the left ground it occupied in 1994. 


\section{The Return to the Left}

Clearly the ANC had multiple objectives in Election 2004, including the 'liberation' of the provinces of KwaZulu-Natal and the Western Cape. Why ordinary citizens need to be 'liberated' from their free and fair choices of previous elections is a little puzzling, but one way of reading this is as election rhetoric intended to rekindle the ANC's liberation credentials. Indeed, this rhetoric makes sense in the face of what many saw as a growing disaffection amongst the ANC's core constituency with a lack of delivery since 1994. As Lodge (2005) notes, the ANC's own research revealed less of a vulnerability on issues of delivery than on the issues of crime,

Table 1

ANC National Election Results 1994-2004

\begin{tabular}{|c|c|c|c|c|c|c|c|c|}
\hline \multicolumn{2}{|c|}{1994} & \multicolumn{3}{c|}{1999} & \multicolumn{3}{c|}{2004} \\
\hline Votes & $\%$ & Seats & Votes & $\%$ & Seats & Votes & $\%$ & Seats \\
\hline 12237655 & 62.65 & 252 & 10601330 & 66.35 & 266 & 10878251 & 69.68 & 279 \\
\hline
\end{tabular}

SOURCE: IEC WEBSITE HTTP:/ / WWW.ELECTIONS.ORG.ZA

Table 2

National Votes for the ANC by Province 1994-2004

\begin{tabular}{|l|c|r|r|}
\hline & $\mathbf{1 9 9 4}$ & $\mathbf{1 9 9 9}$ & $\mathbf{2 0 0 4}$ \\
\hline Eastern Cape & 2411695 & 1617329 & 188892 \\
\hline Free State & 1059313 & 887091 & 838583 \\
\hline Gauteng & 2486938 & 2527676 & 2408821 \\
\hline KwaZulu-Natal & 1185669 & 1176926 & 1312767 \\
\hline Mpumalanga & 1072518 & 962260 & 979155 \\
\hline Northern Cape & 201515 & 211206 & 222205 \\
\hline Limpopo & 1780177 & 1483199 & 1487168 \\
\hline North West & 1325559 & 1052895 & 1083254 \\
\hline Western Cape & 714271 & 682748 & 740077 \\
\hline Total & $\mathbf{1 2} 237655$ & $\mathbf{1 0 6 0 1 3 3 0}$ & $\mathbf{1 0 8 7 8 2 5 1}$ \\
\hline
\end{tabular}


corruption and HIV/AIDS, with several national surveys confirming that unemployment was the issue of major concern for black voters.

In the face of this research, the ANC's focus on the material conditions of poor people is not surprising; indeed many parties talked about similar issues. More remarkable is the left register of the ANC's campaign, which stands in some contrast to the business-friendly tone of Mbeki's first term, founded on the neo-liberal policy of Gear with its commitment to fiscal discipline, privatising state assets and 'good governance', and a record of significant conflicts between government and Cosatu. Indeed, in ideological terms, Mbeki's first term was marked by a twinning of neoliberal pragmatism with an Africanism expressed via the notion of the African renaissance and in the characterisation of South Africa as a society of 'two nations' bound by race. In the run-up to Election 2004 however, the plight of the unemployed and the poor took centre stage, and talk of 'two nations' gave way to 'two economies'. Some may argue that this was not so much an ideological shift as a new phase of government's grand plan, which recognised that 'sound economic policies' form the basis of a 'development strategy to create work and improved opportunities for the millions of South Africans who survive on meagre subsistence activities or on remittances or grants' (Manuel 2004). This has been a recurring motif in the speeches of the Minister of Finance, Trevor Manuel, ever since the introduction of Gear in 1996 (Lodge 1999, pp 23-4). Responding to criticism that Gear had replaced the Reconstruction and Development Programme (RDP) Manuel said that Gear was a precondition for the RDP, not a replacement.

That the 'return to the left' is not a 'return' in that it was always part of the grand plan is not a debate I want to try and settle here, not least as my main argument does not depend on the outcome. Whatever the reasons for the 'return to the left', and however short-lived this return might prove, the evidence suggests that the ANC elite is more concerned about internal challenge from its left flank than about external challenge from the right. This claim is based on three sets of evidence: the nature of the ANC's 2004 election campaign, the ANC's public defensiveness in respect of allegations of 'having failed the poor', and its attempts to patch up strained alliance relations before the election.

Perhaps the clearest statement of the ANC's return to the left was the party's election slogan 'a people's contract to create work and fight poverty' (ANC 2004, p 1). Notably, this slogan echoed the popular language of the 1994 RDP, a language which permeated the manifesto and, indeed, the ANC's entire campaign. A cursory analysis of the content of the manifesto reveals a profound emphasis on issues related to material well-being, like unemployment, poverty and service delivery. This is evident in the way the ANC projected its record in government in respect of water, electricity, housing, education, social grants and the economy. More revealing are the eight components of the ANC's 'Vision 2014', the first two of which are 'to reduce unemployment by half' and 'to reduce poverty by half' (ANC 2004, pp 6-7). Not only are the majority of these 'material' issues, the order suggests that unemployment and poverty are the main priorities. Further, the promises to reduce 
poverty and unemployment by half are specific and bold commitments, more ambitious than 'creating the conditions for one million new, sustainable jobs within five years' as proposed by the DA (2004) or any other party for that matter, and quite striking, as Mbeki has avoided populist policies whilst in government. Indeed, in its manifesto the ANC committed itself to more specific targets for the next five years, including one million jobs through a public works programme and significant investment in infrastructure development.

Other ANC publications reflected similar issues. Thus, the party released two leaflets nationally entitled 'Create Work, Fight Poverty' and 'Safer Communities' [http: / / www.anc.org.za/elections/2004/index.html], and every edition of ANC Today from the ANC's campaign launch on 18 January to the election date of 14 April included at least one piece on uplifting the material conditions of South Africans. The pro-poor emphasis of election materials was reinforced by the style of the ANC's election campaign, which utilised door-to-door campaigning and the media rather than the extensive rallies of the past. While the door-to-door campaign was in part a pragmatic response to limited funds, Lodge (2005) notes that it was also an attempt to demonstrate responsiveness to the plight of ordinary people. This was reinforced by Mbeki's televised high-profile visits to the homes of poor people, a media event aimed at the public at large but nevertheless echoed in the deployment of all ANC leadership, including ministers, members of Parliament and councillors in door-to-door campaigning.

What is remarkable about the ANC's campaign is not just that the party talked about the plight of the poor and visited them in their homes, but that it did this despite the fact that no other major party was engaging the poor in this left-leaning way. Indeed, the ANC made a point of not attacking opposition parties, refusing the DA's attempt to organise a televised debate and generally declining to be drawn into various attempts at agenda setting in the media. In brief, the form and content of the ANC's 2004 election campaign represent something of a shift to the left in the party's public image since 1999. As Jeremy Cronin (2004), Deputy General Secretary of the SACP put it, Election 2004 'was NOT a campaign fought on a programme of privatisation and liberalisation, it was not a programme of labour market flexibility'.

There are two further sources of evidence that affirm the ANC's 'return to the left' in Election 2004. One is the process of reconciliation between the ANC and its alliance partners, especially Cosatu, the other is ANC defensiveness over allegations of having lost touch with the poor. An example of the latter is an article by ANC research co-ordinator Michael Sachs in which he argues that Election 2004 showed both that democratic citizenship is valued in South Africa and that 'the ANC's gains in percentage and absolute terms were especially strong amongst the poorest sections of black and rural electorate' (2004, p 8). A similar claim that the poor believe in the poll' was made in an article in the Mail $\mathcal{E}$ Guardian on 21 May 2004. More revealing, however, are Mbeki's comments at the election victory party of the ANC (Mbeki 2004). Here he said: 
There are some in our country and the rest of the world who had invented stories about our government and our movement. They said we had lost contact with the people. They claimed that the people were angry and disillusioned with the ANC because we had failed to respond to their aspirations. They said that the failures of the ANC government had led to disillusionment and apathy among the youth of our country. They said all we had done was to enrich a few politically well-connected cronies of the leadership of our movement. They claimed that the ANC government was little more than a bunch of corrupt individuals intent on stealing from the people. They said we did not care for the interests of our country's national minorities. They claimed that the traditional leaders were so disaffected that they would mobilise the rural masses to reject our movement. They said the failures of the ANC government had resulted in the birth of so-called social movements that would succeed to persuade our people to boycott the elections. They said that the ANC and the Tripartite Alliance were paralysed by internal divisions and factional fights that would make it difficult for us to act together to reach out to the people of South Africa. This week, more than 10 million South Africans, $70 \%$ of those who voted, categorically rejected all these false accusations.

I think it is significant that, at the moment of victory, Mbeki chose to highlight criticisms of the ANC at all and, moreover, the particular criticisms that he did. These choices indicate a sensitivity to allegations of popular disillusionment caused by enduring joblessness and poverty. It seems safe to infer that these concerns were a significant spur to the ANC's electoral design and its toenadering with Cosatu, especially when many of these popular perceptions were confirmed by the party's own work with focus groups (Lodge 2005). Just as suggestive, however, was the ANC's public rapprochement with its alliance partners in 2003.

The claim that until mid-2003 relations within the alliance were strained was expressed in no less a publication than the ANC Today. The edition of 12-18 October 2001 reported that the ANC was reflecting on its relationship with Cosatu and that the party's National Executive Committee (NEC) was due to hold a series of bilateral meetings with the SACP and Cosatu. According to the paper, 'tensions within the alliance came to a head by Cosatu's general strike against government's programme of restructuring state assets, which coincided with South Africa's hosting of the World Conference Against Racism in Durban. This came against the backdrop of problems in the alliance for at least the last five years, blamed on a range of ideological, policy, strategic, structural and tactical differences.' Further on, the paper states: 'The NEC identified an increasing tendency within the SACP, Cosatu and even the ANC to try to "detach" the working class and working class struggles from the broad multiclass struggle for national liberation ...' It warned of the dangers of this approach: 'Lessons from other struggles teach us that the surest way to defeat the working 
class is to fight a pure class struggle.' It would, in the process, also defeat the struggle for national liberation and social transformation, it said. Similar comments were made in the ANC Today of 18-24 January 2002. In the ANC Today of 19 -25 September, Mbeki affirmed the importance to the alliance of realising the goals of the national democratic revolution, denouncing those who sought to weaken and destroy the alliance by driving 'wedges between the ANC and Cosatu'.

A similar story of tensions within the alliance and moves toward reconciliation emerges from reports on, and press releases from, the SACP and Cosatu. At its eighth National Congress, in September 2003, Cosatu considered and adopted what it called the '2015 programme', its core strategic document for the following ten years. According to the plan (Cosatu 2003, p 7) 'an intense struggle is being waged internally and outside to win the hearts and minds of Cosatu' on three main fronts. First, 'some in the ANC' want 'to encourage "new" unions and workers interested only in shop floor issues. This seeks to transform Cosatu and the labour movement as a whole into salesmen of capital and sweetheart unions, whose main responsibility would be to get workers to "understand" the constraints facing government. This tendency was reflected in the ANC's vicious 2001 briefing notes, which labelled Cosatu, and in particular its leadership, as ultra left.' The second front is a 'weak but increasingly vocal extreme-left group ... impatient with the limits and alliances required in a National Democratic Revolution' and wanting Cosatu to break the alliance and form a workers' party that would challenge the ANC. Third are opposition parties, which recognise Cosatu's power and want to use it to advance their interests.

Further, the 2015 programme ( $p$ ) complains of a shift to the right in government economic policy, with Gear and the rise of a right-wing hegemony in governance brought about by a lack of working-class consultation, especially in the alliance, where Cosatu 'must compete to influence government policies, not just with other civil society formations, but - much worse - with capital itself'. Indeed, 'the balance of forces in the Alliance favours those who want only a limited role for the Alliance and indeed the ANC itself ... In the run-up to elections relations improve and a new sense of unity and respect for one another emerges. Once elections are over we go back to the reality of being sidelined for another five years.' In conclusion, 'the Alliance has been reduced in practice to a crisis manager, mediating mostly between the state and Cosatu. Moreover it has become clear that the state will not necessarily abide by agreements within the Alliance - or for that matter, even ANC resolutions' (Cosatu 2003, p 9).

Nevertheless, the programme concludes, 'the Alliance remains the only weapon in the hands of the people to deepen transformation and take our National Democratic Revolution to new heights ... Above all we recognise that the displacement of the working class leadership of the National Democratic Revolution is temporary, a result of our failure to tilt the balance of forces and manage contestation within the Alliance' (Cosatu 2003, p 10). To redress this imbalance the 2015 programme talks about the need to 'shift the balance of power, debate in the 
Alliance and government' (Cosatu 2003, p 11) through various measures, including playing 'a decisive role in the 2004 elections and shaping the elections platform, and subsequent elections' (Cosatu 2003, p 14).

While the Cosatu congress adopted the 2015 programme, including its recommitment to the alliance and the 2004 election in particular, other proposals that concerned limiting the ANC's powers to appoint premiers and a 20 per cent quota of ANC MPs to be from Cosatu were rejected (The Star 17 September 2003). Writing in the ANC Today Mbeki affirmed the outcome of the Cosatu Congress, stating that 'our alliance has a continuing responsibility to lead our country, a people's contract to push back the frontiers of poverty' (Sapa 19 September 2003). Cosatu President Willie Madisha stated that the union was starting with a 'clean slate' in its relationship with its alliance partners now that tension with the ANC was out of the way (Saturday Star 20 September 2003).

In many ways the rapprochement between the ANC and its key allies was driven by the same sets of concerns that drive party competition in liberal democracies. On the one hand, the ANC needed Cosatu and the SACP for ideological legitimacy and organisational help in winning votes. On the other hand, Cosatu and the SACP need the alliance to influence government decision-making. These incentives of popular support and access to power are the same that motivate opposition parties. I will argue below that the logic of opposition party competition is such that these incentives are, in effect, mutually exclusive. Opposition parties can secure either access to power in conjunction with the ANC or sustained support from voters, but not both. The case with the ANC and the alliance is the opposite, as power and support reinforce each other. The more the alliance gets access to power, the better the ANC does at the polls. Thus, while the relationships of the alliance are framed by the same principles that guide party competition in the political system, their logic is different.

That Cosatu and the SACP took advantage of this rapprochement with the ANC at election time is manifest in a flurry of activity from the two alliance partners after April 2004. For example, on 16 September 2004 Cosatu unions went on the biggest strike in the public sector since 1994 over government's refusal to grant a 7 per cent increase. The strike pitted government against Cosatu, with government making a small concession, increasing its final offer from 6 per cent to 6,2 per cent. It also attempted to visit its fraternal union in Zimbabwe, contrary to government wishes, only to be thrown out of that country. The SACP launched its Red October campaign on land and agrarian reform, pulling together a range of civil society organisations and the ANC behind a review of the land reform process in South Africa, especially the 'willing-buyer, willing-seller' principle (SACP press release 15 October 2004). This direct challenge to current land reform policy has yet to prompt a direct response from government, and seems to indicate a shift of sorts in alliance politics.

Of course the question is how long will this 'return to the left' last? Will Cosatu and the SACP manage to put the alliance at the centre of government decision- 
making, or, as Cosatu's 2015 programme puts it, now that elections are over will the alliance partners be sidelined for another five years? Only time will tell, but early indications are not very positive for Cosatu and the SACP. Whatever transpires, however, the point is that concerns about vulnerability on its left flank significantly affected the nature of the ANC's 2004 election campaign. To what extent the leftleaning nature of the campaign was directly influenced by Cosatu/SACP and to what extent it was engineered solely by the ANC is hard to know. Lodge (2005) makes no mention of alliance input, so perhaps the party chose to frame the campaign in left-leanings terms reminiscent of alliance co-operation around the RDP in 1994 rather than being overtly pushed by its alliance partners.

Translated into terms of party competition for votes this means that the greatest perceived challenge to the ANC in Election 2004 was not from other parties, but from disillusionment born of a left politics most often articulated by the party's alliance partners. This is a politics without a home in the current system of party competition, so it is the politics of a phantom. That the ANC was more concerned about this phantom than about existing parties reveals just how insignificant formal party competition is in South Africa. Nevertheless, I would suggest that these engagements within the alliance do act as a check on the accountability of ANC elites in the name of the working class and the poor. Of course, just how significant this accountability is, is debatable. Habib and Taylor (1999) have argued that the alliance has, on balance, proved ineffectual in enabling Cosatu to influence government policy, especially as the adoption of Gear trumps gains made for workers' rights in laws like the Labour Relations Act and the Basic Conditions of Employment Act. Moreover, as noted above, the Cosatu 2015 programme points out that the alliance partners are largely ignored by government, except at election time.

While it might be true that the influence of Cosatu through the alliance is limited, the question arises whether it would indeed be greater if it were an independent workers' party. I think not. Firstly, it seems unlikely that such a party would defeat the ANC at the polls, and it would have sacrificed its special relationship with the Government to complain from opposition benches. Secondly, the costs of leaving the alliance would be huge. Southall and Wood (1999, pp 78-9) argue that there is a good chance that such a divorce could turn ugly, with the ANC accusing Cosatu of 'betraying the liberation struggle', and leading to 'some combination of a split within Cosatu and within its individual affiliates, bitter struggles of ownership of union assets ... and the formation by the ANC of some rival union'. Further, the new party would have to find resources to fund itself in a world unfriendly to left-wing parties.

Currently, from Cosatu's point of view, a key strength of the alliance is some notion of normative obligation from the ANC thanks to a shared fraternity born of the struggle against apartheid. This fraternity makes it difficult for either side even to imagine leaving without invoking feelings of betrayal. Leaving the alliance effectively means leaving the community of the oppressed, a community whose mission is yet unfinished. This sentiment is reflected in Mbeki's comments that the 
alliance is the 'united response of the oppressed' (Sapa 19 September 2004) and Cronin's (2004) point that Cosatu doesn't want to lobby or bargain with the ANC, but wants 'an ANC (that includes communists and non-communists) united around a national democratic revolutionary programme'. Indeed, the only scenario in which the alliance is likely to split is a somewhat desperate one where economic policy fails and unemployment and poverty rise, creating grounds for a populist reaction, which will probably do more harm than good.

In sum, there are good reasons to assume that the alliance, and Cosatu in particular, helps keep the ANC accountable to an important constituency, even if only at election time, and that this is better done through the alliance than through the formation of a workers' party. Somewhat paradoxically then, in South Africa at this time, elections do deepen government accountability to the organised working class despite the lack of a workers' party. Further, the special relationship forged in the alliance between Cosatu and the ANC means that this is a form of accountability stronger than that likely to be secured by a secessionist workers' party 'traitorous to the struggle'. Of course this argument holds as long as Cosatu remains strong and the sense of a struggle fraternity endures. Indeed, the stronger Cosatu and the SACP become, the more likely it is that they will be able to influence governance between elections as well as for a brief period once every five years. In this respect it is notable that Cosatu's 2015 programme commits it (and urges the SACP to commit itself) to building itself as an organisation and engaging the alliance and government more 'proactively'. Given the foregrounding of unemployment and poverty as the key issues of Mbeki second term, and given the clear determination of the Left to try harder, there is some chance that the 'return to the left' could be more than an epiphenomenon of elections. If so, the ANC's alliance partners might play more of a role in governance in Mbeki's second term than they did in the first.

In conclusion, Election 2004 confirmed both the growing popularity of the ANC and the usefulness of the alliance in securing both a better return for the ANC at the polls and greater Cosatu/SACP influence on government policy, at least during election periods. These findings are largely consistent with those of preceding elections and suggest that, in the case of the ANC, party configurations for popular support and power are mutually reinforcing. For opposition parties the inverse is true. Not only are they increasingly unpopular with the public, but must choose between access to office through co-operation with the ANC and longer-term popularity

\section{The Opposition Parties in Election 2004 Unforeseen Misfortune at the Polls}

As Booysen (2004) notes, Election 2004 provided some 'sobering realisations' for South African opposition parties, whose position is arguably weaker than ever. Table 3 illustrates how, despite the fact that there were more opposition parties on 
the national ballot than ever before, the total percentage of the vote accrued by these parties shrank from 37 per cent in 1994 to 20 per cent ten years later. Further, the support for the largest opposition party has diminished from the 20 per cent of the NP in 1994 to the 12 per cent of the DA in 2004. Indeed, apart from the modest 2,8 per cent growth of the DA in 2004, almost all opposition parties have lost support or held level. The only new party to do well was the Independent Democrats (ID), but even it came in below the United Democratic Movement's (UDM) first-time performance in 1999.

Table 3

Parliamentary Opposition Party Support, National Ballot, 1994-2004

\begin{tabular}{|ll|lc|lc|}
\hline \multicolumn{2}{|c|}{1994} & \multicolumn{2}{|c|}{1999} & \multicolumn{2}{c|}{2004} \\
\hline Party & $\%$ & Party & $\%$ & Party & $\%$ \\
\hline NP & 20,39 & DP & 9,56 & DA & 12,3 \\
\hline IFP & 10,54 & IFP & 8,5 & IFP & 6,97 \\
\hline FF & 2,17 & NNP & 6,87 & UDM & 2,28 \\
\hline DP & 1,7 & UDM & 3,42 & ID & 1,73 \\
\hline PAC & 1,25 & ACDP & 1,43 & NNP & 1,65 \\
\hline ACDP & 0,45 & FF & 0,8 & ACDP & 1,6 \\
\hline & & UCDP & 0,78 & FF+ & 0,89 \\
\hline & & PAC & 0,71 & UCDP & 0,75 \\
\hline & & FA & 0,54 & PAC & 0,73 \\
\hline & & MF & 0,3 & MF & 0,35 \\
\hline & 38,35 & AEB & 0,29 & AZAPO & 0,27 \\
\hline Total $\%$ & & AZAPO & 0,17 & & 30,32 \\
\hline Total votes & $\mathbf{7 2 9 5 8 4 3}$ & & $\mathbf{3 3 , 6 5}$ & & 4734416 \\
\hline
\end{tabular}

SOURCE: SACHS 2004, P 11

Commentators have identified two general problems that beset opposition campaigning in 2004. The first was a lack of obvious differentiation from government on key issues and the policies needed to deal with them (Southall 2004, p 3). As implied in my argument above, this point is not as convincing as it appears at first, for although the ANC might have talked about the same issues as other parties, 
and even shared certain broad policy outlooks, its campaign was situated significantly to the left of those of the main opposition parties. To put the point differently, in respect of content but especially of style, the ANC differentiated itself very effectively from its opponents.

The second general problem (Kotzé 2004; Sachs 2004) was a lower turnout of opposition voters (see Table 3). Kotzé suggests that the timing of the election (immediately after the Easter weekend) might have hurt opposition parties, whose supporters were more likely to have been away on holiday. He also refers to apathy caused by the certainty of ANC victory, and the lack of a viable alternative to the ANC as 'the spectrum of opposition parties was too fragmented and sectoral' (2004, p 2). Sachs (2004, p 12) claims that the lower turnout of the more affluent and the racial minorities was a non-violent form of rejecting democracy by turning to the 'apathy of the cluster home' and/or was due to the lack of appeal of the DA's Leon's robust anti-ANC style. My hunch is that the low turnout had much to do with perceptions of efficacy of participation in the face of a clear ANC victory, a rational choice reinforced by a sense (revivified by the 'ten years of freedom' celebrations) of being on the 'wrong side of history'. In effect, interest and identity combined to erode the motivation of opposition voters to participate, much as it combined to spur the enthusiasm of ANC supporters.

Table 4

Estimated Turnout by Selected Demographic Category

\begin{tabular}{|l|c|}
\hline Demographic Group & Estimated turnout of registered voters \\
\hline Eastern Cape Metro Africans & $84,9 \%$ \\
\hline Western Cape Metro Africans & $82,3 \%$ \\
\hline Gauteng Metro Africans & $76,7 \%$ \\
\hline Limpopo Rural Africans & $75,6 \%$ \\
\hline KwaZulu-Natal Metro Africans & $74,3 \%$ \\
\hline Northern Cape Rural coloureds & $73,6 \%$ \\
\hline Gauteng Metro Indians & $68,4 \%$ \\
\hline Western Cape Metro Indians & $62,0 \%$ \\
\hline KwaZulu-Natal Metro Indians & $61,5 \%$ \\
\hline
\end{tabular}

SOURCE: SACHS 2004, P 10

Aside from these general problems, however, commentators have pointed out various mistakes made by the different parties. Thus, while the DA had some reason to be upbeat about its growth, the party did not realise its election objectives. Firstly, 
its 'coalition for change' with the IFP failed to reach the 20-30 per cent support level it desired. Secondly, the DA did not conclusively consolidate the opposition; securing far less than half the opposition vote, despite the collapse of the NNP1. Thirdly, Booysen (2005) states that the DA's share of the black vote rose from 0,4 per cent in 1999 to 1,7 per cent in 2004, nowhere near the 10 per cent it had hope for. Moreover, these black recruits 'originated in the UDM and the IFP, rather than in the ANC'. Thus, in addition to not consolidating the opposition vote, the DA has made almost no gains amongst government supporters. For Booysen, a major reason for the DA's disappointment was its failure to project a consistent identity to the public, vacillating as it did between liberalism and opportunism. At best, the DA is 'liberal, multi-faceted and engaging in vigorous multi-partyism', at worst it is 'a contradictory-in-terms of policy, internally inconsistent and opportunistic votegarnering apparatus'. Booysen attributes this ambiguity to the problems of unifying a 'broad church of anti-ANC sentiment' from diverse backgrounds and an ambiguity in ideological position and leadership style

The next biggest party, the IFP, had neither the vision nor the resources to prepare and execute a compelling campaign, spending disproportionate amounts outside of its stronghold in KwaZulu-Natal and relying too much on the loyalties of its core rural voters. This was despite being confronted by the ANC's most impressive campaign yet in KwaZulu-Natal. Further, as I argue elsewhere (Piper 2005), the ANC undermined the IFP's attempts to sell itself to opposition voters as an inclusive and competent conservative liberal alternative by continued reference to violence and apartheid-era politics. More generally the IFP finds itself in a dilemma where it can no longer prosecute old-style coercive politics but, because of the deadening effects of the authoritarian leadership style of its leader, Mangosuthu Buthelezi, it struggles to operate as an effective modern party. This failure to transform has left the IFP increasingly vulnerable to the better organised and better led ANC. Recent attempts to rectify this problem have been simply too little too late. The party has lost the key benefit of being in power in KwaZuluNatal and it is hard to see how the ANC will now let slip its advantage.

In respect of the rest of the minority parties, the NNP's 'dizzying flight from government to opposition and back' undermined its already waning credibility in the eyes of voters (Southall 2004, p 5). Consequently, its more conservative supporters left for the DA, and the more left leaning headed to the ANC. Further, poor organisation and a lack of resources saw parties like the UDM, the Pan Africanist Congress (PAC) and the Azanian People's Organisation (Azapo) holding steady at best. With the exception, perhaps, of the African Christian Democratic Party (ACDP), the rest of the opposition parties were no real threat to start with.

While these subjective party weaknesses are important, it is my view that they may explain gains and losses made amongst opposition parties but they do

1 Notably, where the combined DP/NP support in 1994 was 22,12 per cent, the combined DP, NNP, FA support in 1999 was 16,97 per cent and in 2004 it was 14 per cent. 
not really explain the overall decline in the opposition vote. Winning votes from opposition parties is one thing, winning votes from the ANC is another altogether, and something that even a party which had consolidated all 30 per cent of the opposition vote would struggle to do. Simply put, there is just so much an opposition party can do given the dominance of the ANC, and indeed there is more to the dominance of the ANC than good governance and good campaigning.

Key here are the attitudes of ordinary South Africans. To my mind a significant proportion of the ANC's supporters endorse the party because they see it as the party of the oppressed, and the oppressed still need (mostly economic) liberation in the new South Africa. This reasoning is based on observation of the patterns of party political affiliation since 1994 . Two claims are important here. First, the past three national elections have revealed that the divide between the ANC and the opposition parties is not sociologically random but follows certain widely acknowledged social categories. More specifically, the supporters of the ANC are overwhelmingly those who were the losers under the apartheid system: black and poor people. Conversely, those who were (relatively speaking) the 'winners' under apartheid, namely racial minorities, the wealthy and some Bantustan beneficiaries, support opposition parties. This bifurcation of popular support is testimony to the enduring and powerful legacy of apartheid. Thus, while the size and ranking of opposition parties has changed quite dramatically since 1994, the overall levels of support and the profile of opposition voters has not changed much at all. In addition, with the exception of some losses by the IFP and NNP to the ANC in the last election, very few voters have changed from one side of the apartheid divide to the other.

Second, this suggests that, until the racial, class and ethnic bases of power are reconstituted, party competition occurs largely within one of these two groups so that the ANC, PAC, Azapo, and so on, contest the 'apartheid losers' group, and the DA, NNP, IFP, UDM and UCDP contest the 'apartheid winners' group. In practice then, opposition electoral politics has been a zero-sum gain amongst opposition parties rather than between opposition parties and the ANC. In this context the strengths and weaknesses of parties help explain how they do within each group, but there is little that parties can do in the short term to win support across group boundaries. Of course both these claims are somewhat crude and require further nuance. The ambiguous position of traditional leaders and of racial minorities like Indian and coloured people needs further investigation, as do the emergent changes in racial, class and ethnic relations. Nevertheless, it is my view that the general description stands and that, when added to the quest for political office - the raison d'être of political parties - it introduces the central dilemma of opposition politics: access to office versus popular support.

\section{The Dilemma of Popularity Versus Power}

In the context of a bifurcated electorate where the vast majority return the ANC, opposition parties have very little chance of winning office. This means that, in 
order to hold office, opposition parties find themselves forced to consider alliances either with each other, in the rare circumstance that this is possible, or with the ANC. The most significant example of an opposition party alliance for power was the NNP/DA alliance after election 1999 to secure the government of the Western Cape despite the ANC being the largest party in the province. However, other instances have occurred at local government level. Indeed, after the 2000 local government elections the DA and the IFP agreed to share power in local councils wherever possible.

On the whole, though, party coalitions for power have more commonly seen opposition parties making some arrangement with the ANC. In 1994, 1999 and 2004 the ANC and the IFP agreed to various power-sharing arrangements in the national and KwaZulu-Natal governments on a quid pro quo basis such that IFP access to national power was traded for ANC access to KwaZulu-Natal. While, from the IFP's point of view, this arrangement was driven by a desire for power, from the ANC's standpoint it was more about reducing conflict in KwaZulu-Natal. Experience of IFP brinkmanship during the transition years had taught the ANC leadership that IFP compliance was better achieved through inclusion and recognition (especially of Buthelezi) than through exclusion (Piper 2000).

It is my view that this cooperation between the IFP and ANC has hurt the IFP in two ways. First, it has directly undermined the IFP in the eyes of (mostly white) opposition voters looking for a robust challenger to the ANC. This is a constituency the IFP has targeted in every election since the 1996 local government elections with decreasing success over time. Thus, where the party secured something like one-third of white voters in KwaZulu-Natal in the provincial ballot of 1994 (Piper \& Piper 1995), this proportion had declined significantly by 2004. Perhaps part of the reason for this is the IFP's unremarkable record in government in KwaZuluNatal, but another is its ambiguous relationship with the ruling party. This conclusion is affirmed by the fact that, today, most white and many Indian voters in KwaZulu-Natal support the DA, with its vigorous anti-ANC stance. Second, cooperation in government with the ANC has moderated the IFP's militant Zulu nationalism of the transition years, creating the opportunity for the ANC to gain increasing access to IFP supporters and to win over more and more significant numbers with each election. Such is the shift in popular support since 1994 that the claim that rural Zulus of KwaZulu-Natal support the IFP and urban black voters endorse the ANC is no longer true. By Election 2004 the IFP had shrunk to a constituency of rural Zulu people north of the Tukela, with most rural people in the south endorsing the ANC.

Perhaps the best known alignment for power between an opposition party and the ANC involved the NNP. Following the successful coalition between the NNP and DP which won them power in the Western Cape after election 1999, the NNP under its new leader, Marthinus van Schalkwyk, and the Federal Alliance (FA) entered into a formal alliance with the DP called the Democratic Alliance. This alliance contested the local government elections of October 2000. Shortly thereafter, 
however, Van Schalkwyk decided to withdraw the NNP from the DA as 'he and his ilk were unable to stomach playing second fiddle to the more cerebral and feisty Tony Leon and engaging in the politics of vigorous opposition' (Southall 2004, p 5). Then, following the floor-crossing period of 2002-3, Van Schalkwyk decided to join up in a loose coalition with the ANC to seize control of the city of Cape Town and the government of the Western Cape. According to Southall $(2004, \mathrm{p}$ 5) the ANC played to Van Schalkwyk's 'personal ambition for office, his party's lack of commitment to principled opposition and its lingering lust for power', in a 'blatant case of a cynical, up-and-coming bridegroom marrying a vainglorious elderly widow for her tawdry wealth'. Whatever the reasons, the NNP's behaviour cost it hugely in the 2004 polls, and shortly afterwards the party decided to merge with the ANC.

In short then, the lesson to be learned by opposition parties is that co-operation with the ANC may help with access to political office in the short term, but it is likely to cost votes over time, with (mostly white) anti-ANC voters going to the DA and (many black) supporters switching to the ANC. This reflects the fact that the boundary between government and opposition supporters is perhaps becoming more porous, but mainly in one direction, with some black opposition support now moving to the ruling party. My view, which space prevents from developing here, is that this has something to do with changing social relations in post-apartheid South Africa and, more directly, with the ANC's capture of key elites.

In contrast to the lesson that co-operation for power costs votes, there are a couple of opposition parties, principally the DA and perhaps the ID, who have benefited at the polls because of an overt challenge to ANC power. The DA's record in this respect is well known, and mostly associated with the advent of Tony Leon as party leader after the 1994 election. As Southall (2004, p 5) puts it, 'Leon takes delight in pinning his criticisms of the ANC to the mast, and sailing into battle. He loves the smell of blood, the electorate senses it, and some buy his fighting message gladly.' In the 1999 election this confrontational anti-ANC politics was expressed in the party's 'fight back' campaign, which succeeded in drawing large numbers of mostly white NNP voters disgruntled with their party's cuddling up to the ANC. Confronted by accusations that it was appealing to racial prejudice (the ANC pilloried 'fight back' as 'fight blacks'), in more recent times the DA has looked to take its campaign to the townships and has formed the coalition for change with the IFP to 'oppose the ANC at a national level and co-govern at provincial and municipal levels' (Leon 2003).

While it is clear that the DA's anti-ANC position has greatly boosted its popular support, this is clearly a support with a ceiling. Indeed, Election 2004 suggests this ceiling is well below the 30 per cent mark of opposition voters. Further, attempts to win over black converts have not really worked, despite the work in the townships and alliance with the IFP. Indeed, to my mind the coalition with the IFP undermines the DA's attempts to win black voters, given the widespread popular perception of the IFP as 'an apartheid collaborator' and 'ethnically chauvinist' (Southall 2004, p6). 
The lesson of the last few elections is that overt challenge to the ANC may mean foregoing political office, but it is one way of winning votes. In many ways, the success of Patricia de Lille's Independent Democrats in Election 2004 confirms this pattern. The ID's success had much to do with De Lille's public image as a robust critic of the ANC and with the fact that she is a former PAC leader with good struggle credentials (Hoeane 2005).

The voting patterns for opposition parties since 1994 suggest that access to power through co-operation with the ANC sits in some tension with popular support amongst opposition voters, especially white opposition voters. When added to the analysis of ANC support, this pattern confirms the picture of the South African electorate as divided most profoundly into two groups: poor black people who support the government and racial minorities, the wealthy and some Bantustan constituencies. This apartheid boundary has proved remarkably important in the last three national elections, with the percentage and identity of opposition support remaining pretty constant, especially if one considers the reduced turnout of opposition voters in 2004. What this means is that opposition parties must either resign themselves to a future with little power but a good chance of retaining opposition votes (like the DA), or access to power through some arrangement with the ANC, but at great risk to their future support (like the NNP and IFP).

However, this not the end of the story, as Election 2004 provided evidence that the boundary between apartheid 'winners' and 'losers' is become more porous, although mostly in one direction - from the opposition to the ANC, and mostly from groups of opposition voters who were only comparatively winners under apartheid: coloured minorities and Bantustan constituencies. This is obviously good news for the ANC and bad news for the opposition parties, especially those like the DA that rely on strong anti-ANC sentiment. It also suggests that under Tony Leon's confrontational anti-politics the DA may fast be approaching its ceiling amongst opposition supporters.

\section{Future Party Configuration}

Describing these trends is one thing, explaining them is another. So far I have largely avoided explanation, other than to suggest that the fundamental divide in the South African electorate places limits on the significance of subjective factors of party performance. Thus, no matter how hard it tries, the ANC may be reaching the zenith of popular support unless opposition voters dramatically change their beliefs. Similarly, no matter what it does, the DA's consolidation of the opposition vote limits it to 30 per cent of the popular vote, and probably far less under Tony Leon. To put the matter another way, I have stated that the boundary between government and opposition voters is based on deeper relationships and identities from the apartheid era, more specifically, enduring racial, class and ethnic power relations. However, these relations are changing, albeit to various degrees. While what follows is not, by any stretch of the imagination, a through assessment, I will make a few 
comments about the trajectory and pace of these changes and what they might mean for future party politics.

To my mind there are three major axes of social change in South Africa that follow the institutions of state, market and public sphere. First, there have been dramatic changes in the institution of the state, which are eroding the racial and ethnic power relations of the apartheid era, both in respect of the exclusion of black South Africans from voting and from office in branches and levels of direct rule in urban areas, and the ethnically-couched configurations of indirect rule in rural areas (Mamdani 1996). However, this movement is not absolute. The realities of demography mean the non-racial state is de facto racialised in personnel and, more importantly, in some policies. This trajectory is reinforced by the propagation of race thinking in the discourse of transformation and ANC ideology as well as in lingering racism among many 'apartheid winners'. Perhaps unavoidably, perhaps unintentionally, race retains a radically reduced but still significant link to state practice, if not explicit state design. It is this variable which places limits on the openness of racial minorities to the ANC. In respect of ethnic power, the ambiguous status of traditional leaders in state design effectively slows the decay of undemocratic governance, if not government, in many rural areas. This is a key factor in maintaining IFP support, and helps explain why, unlike the NNP, the IFP will not suddenly collapse.

Second, there have not been fundamental changes in the institutions of the economy and this has perpetuated much of the racial character of the class divide in South Africa. Some important caveats apply, however, the most significant of which is the growth of a black middle class in South Africa, chiefly through access to resources of the state, but increasingly through policies of black economic empowerment in the market place. Also significant has been greater class inequality within all racial groups. Taken together these suggest that class divides are beginning to cross cut racial divides, unlike the isomorphism of race and class under apartheid. Critically, the untangling of race and class is lopsided in that, to date, it has mostly been about the emergence of a multiracial middle class, but the working class and poor have remained disproportionately black and are arguably worse off than they were in 1994. In political terms this dynamic is expressed in tensions within the alliance, especially between government and Cosatu and, as reflected in party behaviour, is the most important challenge for the ANC leadership to contain.

Third, there have been significant changes in the public sphere which have great cultural significance. While the public sphere is a more ambiguous entity to define than state and government, economy and market, I use it here to refer to the realm of public debate and it is markedly influenced by the reformed state and enduring market players. This influence is exercised through systems of mass communication, especially 'global' communication, with its Americanised popular culture and westernised 'modern' political culture. Perhaps the least anticipated of the major institutional changes, the partial 'globalisation' of South Africa's public realm, is still powerful and has implications for popular and political culture, as is 
poignantly manifest in the often 'cosmopolitan' quest for cultural identities evident among the younger members of South Africa's 'first economy'. In this context the resonance of Africanism is not irrelevant as much as transformed into forms that seek admission to the world. The resonance of Africanism within the 'second economy' is likely to be quite different and constructed in terms we are more familiar with, not least xenophobia towards immigrants.

In sum, the overall trajectory of institutional and cultural change since 1994 is changing apartheid political identities, albeit in different ways and at different speeds. On the one hand, the ascent to power of black leadership combined with the enduring economic position of most black people has opened tensions within the black community (represented in alliance politics) and has reinforced a sense of collective unfinished business. The ANC has been wise enough to turn this to its advantage, using a semi-racialised communitarianism to trump class divides. Nevertheless, blackness is not what it used to be. On the other hand, opposition voters' fear of ANC (and perhaps black) rule is being eroded by experience of relatively competent government which has mostly secured the interests of the middle classes and above. The ANC has been very successful in incorporating into its governance many of this elite, especially the less privileged of the apartheid era 'winners'.

To my mind the real struggle for the future of South African party politics lies in the recruitment of the middle class, as it is they who dominate government, the market and the public sphere. In this respect the major challenge for the ANC is to maintain the support of both the powerful middle classes and poor black people. Hence it is more (if still only moderately) concerned about an internal left politics represented in the alliance than it is about opposition parties. For opposition parties, and especially the DA, the major challenge is race politics. Can it, in the next five years, start to overcome its white middle-class image to transform itself into a party for the black middle classes? While the party has made some tentative moves, they are far too modest and are undermined by the historically racialised thrust of Leon's approach. To its commitment to opposition, the DA needs to add credible black leadership and especially a new leader, preferably someone with struggle credentials. It also needs a clear strategy for recruiting the black middle classes. Clearly then, the competitive challenges for the opposition are far higher than those for government. It is hard to imagine the opposition making significant gains unless government begins to slip up, and the chances of that are remote under President Mbeki. Real challenge might be possible under a new president, and, if it is to have any hope of growing in future elections, the DA needs to prepare for that distant opportunity.

\section{CONCLUSION}

Election 2004 has confirmed the dominance of the ANC in terms both of popular support and of control over political office. That much is common knowledge. 
However, the election also revealed some significant changes. In respect of the ANC these involved a 'return to the left' in the content, but especially the style, of its election campaign. When added to a certain public defensiveness and rapprochement in the alliance, ANC electioneering suggests a greater concern with an internal left politics than with extant opposition parties.

Election 2004 also revealed that the alliance is good for all its members, at least during election time, as it boosts ANC support and Cosatu/SACP influence over government. Moreover, there are good reasons to believe that, during election time especially, the alliance helps keep the ANC somewhat accountable to labour, and more effectively than would an independent workers' party. Thus, contrary to the liberal-pluralist model and to the expectations of many commentators, government accountability is currently not better served through competition from a workers' party than through existing non-party channels.

In contrast to the growing popularity of the ANC and the synergies of alliance configuration, Election 2004 revealed declining opposition support and the dilemma of popularity-versus-power-sharing that faces opposition parties. This means that opposition parties must either resign themselves to a future with little power but some potential for growth, or access power through some arrangement with the ANC, but at great risk to their future survival. Opposition politics centres on trading off marginality but long-term survival against short-term, but short-lived, power.

This paper also suggests that the dynamics of party configuration for support and political office are only partly explicable in terms of subjective party choices. Also important is a fundamental and enduring divide in the electorate between poor black people who were the unambiguous 'losers' under apartheid and wealthy racial minorities and Bantustan constituencies who were comparative 'winners'.

Where changes in racial, class and ethnic power relations are beginning to redefine popular interests and identities, this is an uneven process which is producing a multiracial middle class, still marked by racial divides, but increasingly distinct from the huge class of poor black people. While these changes are starting to see the ANC recruit from the black members of the apartheid 'winners' category, it also suggests that marrying this with working-class interests will be the party's largest challenge. Conversely, the DA needs to recruit from the black middle classes whilst retaining an oppositional stance if it is meaningfully to challenge the ANC for support and office in 2009. This looks the far harder task. The DA will not only have to overcome perceptions of racial exclusivity but also the ANC's effective control of key social resources and domains. This is highly unlikely outside of a widespread failure of government, especially in the economic realm.

What, then, is the future of party alignment in South Africa? If current trajectories continue we can expect, on the one hand, the ANC's domination of popular support and office to increase as it absorbs a larger share of opposition support and leadership, especially from the IFP. Indeed, I would suggest that this would be guaranteed if the ANC could demonstrably deliver on the issues of jobs and poverty in the next five years. In this context we can also expect the ANC to be 
more concerned about alliance relations and class politics than about the challenge from opposition parties. On the other hand, we can expect the oppositional stance of the DA to continue to secure it more support, but in a shrinking pool of opposition voters and parties, until it approaches a ceiling well under the 20 per cent mark.

\section{REFERENCES}

ANC. 2004. Manifesto 2004: A People's Contract to Create Work and Fight Poverty. [http: / / www.anc.org.za/elections / 2004/manifesto/manifestoprt.html] Booysen, S. 2004. 'Ten Years of Democracy and the State of Opposition Politics in South Africa'. Election Update 2004 South Africa 8, 3 May.

- 2005 (forthcoming). 'The Democratic Alliance'. In J Piomba and L Nijzink (eds). Contested Terrain: Electoral Politics in South Africa's First Democratic Decade. Houndmills, Basingstoke: Palgrave.

Cosatu. 2003. Toward 2015 Programme. Cosatu $8^{\text {th }}$ National Congress, 15-18 September, Gallagher Estate, Midrand. [http://www.cosatu.org.za/ cong2003/ congweb/2015.html]

Cronin, J. 2004. 'What are the challenges of the working class going into the second decade of freedom?' Address to NUM Special Congress, 6-8 May. [http:/ / www.sacp.org.za/docs/ speeches / 2004/sp0507.html]

DA. 2004. The Democratic Alliance 2004 General Election Manifesto. [http:/ / www.da.org.za/da/Site/Eng/campaigns/2004/manifesto.asp]

Habib, A and R Taylor. 1999. 'Respond to Southall and Wood's: Cosatu, the ANC and the Election: Whither the Alliance?'. Transformation 40.

Hoeane, T. 2005 (forthcoming). 'The Pan Africanist Congress (PAC), the Azanian People's Organization (Azapo) and Independent Democrats (ID)'. In J Piomba and L Nijzink (eds). Contested Terrain: Electoral Politics in South Africa's First Democratic Decade. Houndmills, Basingstoke: Palgrave.

Kotzé, D. 2004. 'Post-Election Phase Election Results and Election Review'. Election Update 2004: South Africa 8, 3 May.

Leon, T. 2003. 'Tony Leon proposes a “coalition for change"'. [http: / / www.da.org.za/da/Site/Eng/Speeches/Speech.asp?ID=513]

Lodge, T. 1999. 'Policy Processes within the African National Congress and the Tripartite Alliance'. Politikon 26(1), pp 5-32.

_ 2004. 'The ANC and the Development of Party Politics in Modern South Africa'. Journal of Modern African Studies 42(2).

_. 2005 (forthcoming). "“Ayikho efana nayo; there is no party like it": The African National Congress's Election Campaign in 2004'. In J Piomba and L Nijzink (eds). Contested Terrain: Electoral Politics in South Africa's First Democratic Decade. Houndmills, Basingstoke: Palgrave.

Mamdani, M. 1996. Citizen and Subject: Contemporary Africa and the Legacy of Late Colonialism. Cape Town: David Philip. 
Manuel, T. 2004. Address to the National Assembly by Minister of National Treasury, T Manuel, on the Tabling of the Medium Term Policy Statement, the Adjustment Appropriations Bill and the Revenue Laws Amendment Bill, 26 October.

Mbeki, T. 2004. Statement at the Election Victory Party of the ANC. Johannesburg, 16 April. [http: / / www.anc.org.za/ancdocs / history/mbeki / 2004/ tm0416.html]

Piper, L. 2000.'The Politics of Zuluness in the Transition to a Democratic South Africa'. Doctoral thesis. University of Cambridge.

2005 (forthcoming). 'Between the Impossible and the Ineffective: The IFP election campaign of 2004'. In J Piomba and L Nijzink (eds). Contested Terrain: Electoral Politics in South Africa's First Democratic Decade. Houndmills, Basingstoke: Palgrave.

Piper, L and S Piper. 1995. 'Hit \& Myth: Zulu Ethnicity and the 1994 Elections in KwaZulu-Natal'. Presented at the South African Political Studies Association (SAPSA) Conference, University of Stellenbosch, 27-29 September.

Reynolds, A. 1994. 'The Results'. In A Reynolds (ed). Election '94 South Africa: The Campaigns, Results and Future Prospects. Cape Town: David Philip.

Reynolds, A. 1999. 'The Results'. In A Reynolds (ed). Election '94 South Africa: From Mandela to Mbeki. Cape Town: David Philip.

Sachs, M. 2004. 'Voting Patterns in the 1999 and 2004 Elections Compared'. Election Synopsis 1(4).

Schumpeter, J. 1987. Capitalism, Socialism and Democracy. London: Unwin.

Southall, R. 2004. 'Goliath's Victory'. Election Synopsis 1(4).

Southall, R and G Wood. 1999. 'Cosatu, the ANC and the Election: Whither the Alliance?' Transformation 38. 